\title{
Modelling impact of bottom roughness on sea surface temperature in the Sea of Iroise.
}

\author{
N. Guillou ${ }^{\mathrm{a}, *}$, G. Chapalain ${ }^{\mathrm{a}}$, E. Duvieilbourg ${ }^{\mathrm{b}}$ \\ ${ }^{a}$ Laboratoire de Génie Côtier et Environnement, DS, CETMEF, 155 rue Pierre Bouguer Technopôle \\ Brest-Iroise - BP 5 - 29280 Plouzané, France \\ ${ }^{b}$ Laboratoire des Sciences de l'Environnement Marin - UMR 6539, Institut Universitaire Européen de \\ la Mer, Place Nicolas Copernic, 29280 Plouzané, France
}

\begin{abstract}
A hydrological model based on the coupling of the three-dimensional hydrodynamic module COHERENS (COupled Hydrodynamical-Ecological model for RegioNal and Shelf seas) with the wave propagation module SWAN (Simulating WAves Nearshore) is used to study the effects of bottom roughness on sea surface temperature (SST) in the nearshore areas of the Sea of Iroise (western end of french Brittany). Predicted time histories of SST are compared with available field data collected at two offshore stations and along the route of a vessel travelling between the coast and the isle of Ushant. The comparison is extended to SST spatial distribution derived from remote-sensing observations for conditions characterizing the development of horizontal thermal fronts in the Sea of Iroise. A numerical sensitivity study is conducted focusing on the impacts of the heterogeneous bottom roughnesses associated with (i) the granulometric distribution of seabed sediments and (ii) the apparent friction induced by the waves in the bottom boundary layer. Whereas moderate differences are obtained, both bottom-roughness distributions are found to influence the predicted SST leading to slight improvements of global predictions. The sensitivity of numerical simulations is exacerbated in areas of high thermal gradients. The effects of the bottom roughness associated with the seabed are thus revealed at the north-eastern and south-eastern edges of external Ushant thermal front. Waves have a major influence in the nearshore areas of the bay of Audierne and the western extend of Crozon peninsula.
\end{abstract}

Keywords: Ushant front, tide, wave, COHERENS, SWAN, SIRANO.

\footnotetext{
${ }^{*}$ Corresponding author

Email addresses: nicolas.guillou@developpement-durable.gouv.fr (N. Guillou ), georges.chapalain@developpement-durable.gouv.fr (G. Chapalain), eric.duvieilbourg@univ-brest.fr (E. Duvieilbourg)

Preprint submitted to Continental Shelf Research
} 


\section{Introduction}

The Sea of Iroise is a shallow environment (Fig. 1) located at the western end of french Brittany with strong tidal currents reaching $4 \mathrm{~ms}^{-1}$ near the isle of Sein (e.g., SHOM, 1968; Mariette et al., 1982). This intense hydrodynamic results in water depths between 50 and $90 \mathrm{~m}$ in a well-mixed water column with extremely weak temperature variations between the surface and the bottom whenever restratification associated with atmospheric fluxes is not able to overcome the effect of mixing (Mariette and Le Cann, 1985). In spring and summer, a strong stratification establishes with the generation of offshore and nearshore thermal fronts such as the dominant Ushant front appearing at the west of the isles of Sein and Ushant which separates tidally mixed coastal waters from thermally stratified offshore waters (e.g. Pingree et al., 1977; Le Boyer et al., 2009).

In addition to field observations (Le Corre and Mariette, 1985), numerous models have largely contributed to a better knowledge of the formation of these thermal structures. The roles of barotropic tides and wind-induced vertical mixing have been revealed by unidimensional (1D) (Altazin-Pichon, 1981; Mariette, 1983) and bidimensional (2D) (Mariette et al., 1982; Mariette and Le Cann, 1985) modelling studies. More recently, three-dimensional (3D) models (Cambon, 2008; Muller, 2008) have focused on the residual and lagrangian water mass transports associated with these hydrological structures.

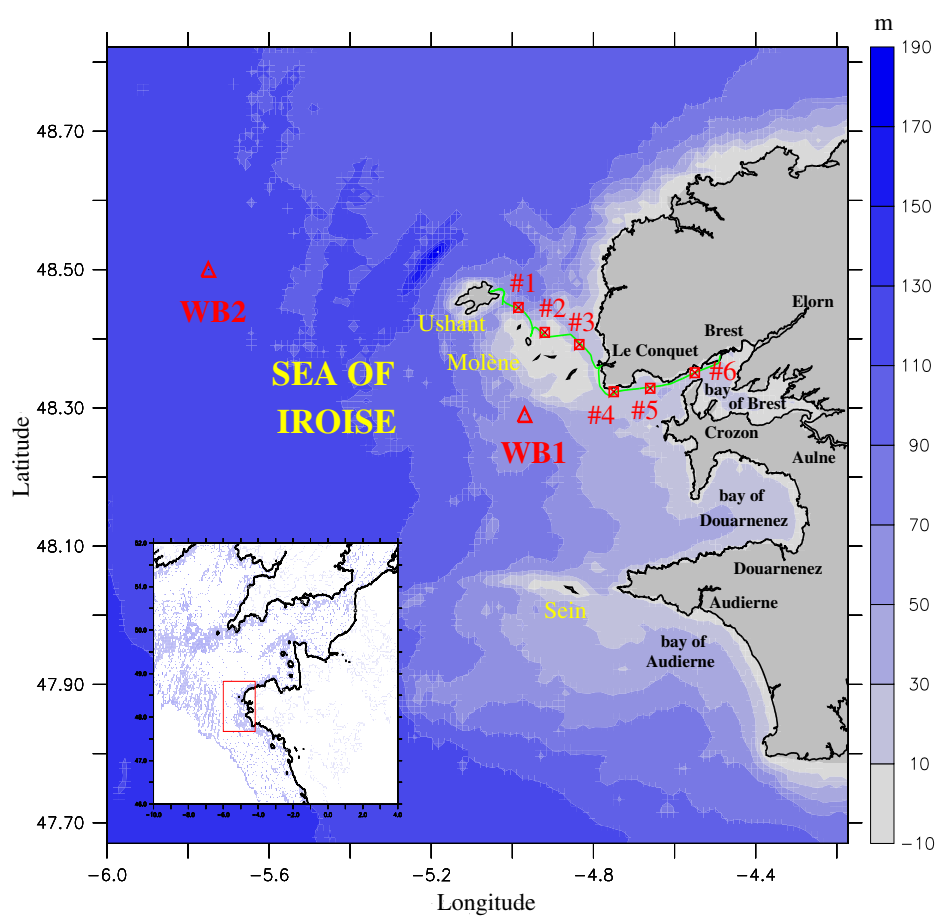

Figure 1: Bathymetry and computational domain \#1. Red squares show locations selected for the extraction of SST time series along the averaged vessel path displayed by the green line. Red triangles indicate the positions of the available offshore wave buoys WB1 and WB2. The left-bottom inset displays the position of the computational domain \#1 in the North-East European continental shelf. 
Nevertheless, the influence of bottom-friction parameterizations was poorly addressed. Simulations used to assume uniform bottom-roughness parameters neglecting the effects of the heterogeneous distribution of seabed sediments and the waves in the bottom boundary layer. These aspects deserve however some attention in a region with (i) quite heterogeneous bottom sediments including silts, sands, gravels and rock outcrops (e.g., Hinschberger et al., 1968; Augris et al., 2005) and (ii) significant exposure to North Atlantic wind-generated surface-gravity waves (Benoit and Lafon, 2004).

The purpose of the present study is to investigate the effects of bottom roughness parameterization on modelling of sea surface temperature (SST) in the Sea of Iroise. The approach relies on a comparison between numerical predictions and observations. In-situ measurements are realized (i) nearshore along the route of a vessel travelling between the coast and the isle of Ushant and (ii) offshore at two fixed-point stations (section 2.1.1). These observations are completed by SST satellite images (section 2.1.2). Modelling is based on the coupling between a wind-generated surface-gravity wave module (section 2.2.1) and a 3D circulation module integrating the advective and diffusive transports of temperature and salinity (section 2.2.2). Numerical predictions are compared with observations over the period from April to October 2011 when nearshore SST measurements are available (sections 3.1.1 and 3.1.2). These comparisons exhibit (i) the seasonal and spring-neap tidal variabilities of SST and (ii) the main associated-hydrological features such as the dominant Ushant thermal front. Modelling is exploited to conduct a sensitivity study on the effects of the heterogeneous bottom roughnesses associated with (i) the granulometric distribution of seabed sediments and (ii) the apparent friction induced by the wave in the bottom boundary layer (section 3.2). Improvements of numerical predictions with respect to available satellite observations are displayed (section 3.2.1). Spatial and temporal changes in predicted SST are quantified further with mappings of induced differences in the nearshore areas of the Sea of Iroise (section 3.2.2).

\section{Materials and methods}

\subsection{Observations description}

\subsubsection{In-situ data}

Measurements here used were provided by the "Ships-of-Opportunity" (SoO) project SIRANO ("Surveillance des eaux de surface en mer d'Iroise et RAde de Brest par des Navires d'Opportunités"). The principal advantage of SoO systems is to increase the temporal and spatial coverages of in-situ measurements at a fine resolution in the coastal areas (e.g., Petersen et al., 2008; Grayek et al., 2011). SoO systems can thus provide valuable information on water and temperature transports over large regions when combined with other observations like remote sensing data. Indeed, nearshore satellite images constitute most of the time a database of scattered observations with a time step often too large to catch surface heating processes like the cooling of surface water (e.g. Grayek et al., 2011). SIRANO operates two times per day SST measurements along the route of the "Enez Eussa III" vessel between Brest and the isle of Ushant (Fig. 1). The instrumentation system consists of a multiparameter probe YSI 6920V2-2-M in direct contact from a continuous flow of seawater taken at a water depth of $1.4 \mathrm{~m}$ under the sea surface. The basic sensors measure temperature, salinity, turbidity, $\mathrm{pH}$ and chlorophyll-a fluorescence. The observations used in the present study are restricted to the SST. The rate of 
acquisition is set to $0.1 \mathrm{~Hz}$ which provides measurement at an averaged spatial resolution of $100 \mathrm{~m}$. SIRANO integrates also a Global Positioning System (GPS) for the location of the measuring points. This device is connected to a station on shore for data transfer, archiving and dissemination on a web site (http://www.memphys-lgce.fr.ht/). More details about the instrumentation system are given by Duvieilbourg et al. (2012). Measurements here used were only available till October 2011 as the "Enez Eussa III" vessel was replaced in autumn 2011. Data were processed to extract time series of SST measurements at six fixed-points evenly spaced along the route of the averaged vessel path over the period of interest from April to October 2011 (Fig. 1 and Table 1). The method here retained has consisted in gathering data collected at a distance less than $500 \mathrm{~m}$ of these points. Statistical analysis performed on GPS data exhibits the regularity of the vessel path between the harbours of Brest and Le Conquet. Whereas the route is liable to change a little more in its offshore part, the treatment allows to acquire at least one measurement per day at every location.

\begin{tabular}{ccccc}
\hline $\begin{array}{c}\text { Point } \\
\text { measurement }\end{array}$ & \multicolumn{2}{c}{ Coordinates } & $h_{\text {mean }}$ & $z_{0}$ \\
Long. & Lat. & $(\mathrm{m})$ & $(\mathrm{mm})$ \\
\hline$\# 1$ & $4.99^{\circ} \mathrm{W}$ & $48.45^{\circ} \mathrm{N}$ & 57.8 & 3.3 \\
$\# 2$ & $4.92^{\circ} \mathrm{W}$ & $48.41^{\circ} \mathrm{N}$ & 18.9 & 3.3 \\
$\# 3$ & $4.83^{\circ} \mathrm{W}$ & $48.39^{\circ} \mathrm{N}$ & 27.7 & 3.0 \\
$\# 4$ & $4.75{ }^{\circ} \mathrm{W}$ & $48.32^{\circ} \mathrm{N}$ & 22.7 & 3.1 \\
$\# 5$ & $4.66^{\circ} \mathrm{W}$ & $48.33^{\circ} \mathrm{N}$ & 18.5 & 0.5 \\
$\# 6$ & $4.55^{\circ} \mathrm{W}$ & $48.35^{\circ} \mathrm{N}$ & 22.9 & 1.5 \\
WB1 & $4.97^{\circ} \mathrm{W}$ & $48.29^{\circ} \mathrm{N}$ & 66.7 & 2.9 \\
WB2 & $5.75^{\circ} \mathrm{W}$ & $48.50^{\circ} \mathrm{N}$ & 119.5 & 3.5 \\
\hline
\end{tabular}

Table 1: Coordinates, mean water depths and bottom roughnesses associated with the heterogeneous distribution of seabed sediments at every measurement sites.

SIRANO observations are complemented by measurements at two offshore wave-buoy stations WB1 $\left(\lambda=4.97^{\circ} \mathrm{W}, \phi=48.29^{\circ} \mathrm{N}\right)$ and WB2 $\left(\lambda=5.75^{\circ} \mathrm{W}, \phi=48.50^{\circ} \mathrm{N}\right)(\mathrm{Fig}$. 1 ). Both stations are part of a measurement system of waves parameters (significant wave height, period and direction) and SST in the Sea of Iroise. The water temperature sensor is located at each stations in a pocket in the interior of the mooring eye in direct contact with the metal. Measurements were performed at depths of 0.4 and $1 \mathrm{~m}$ below free surface at stations WB1 and WB2, respectively. SST data were however missing at both measurement points at the end of the period of interest in relation to malfunction of the instrumentation systems. Wave observations were also lacking: at the end of September 2011 at station WB1 and the end of November 2010 at station WB2.

\subsubsection{Remote sensing data}

Daily-SST remote-sensing data are derived from the observations of the european ocean-SST multi-sensor L3 provided by MyOcean (European Commission) project (http: //www.myocean.eu/). Multi-sensor data are built from bias-corrected L3 mono-sensor products at the spatial resolution of $0.02^{\circ}$. If the native collated resolution is below $0.02^{\circ}$, the distributed resolution is reached by averaging the best quality data. If the resolution is over $0.02^{\circ}$, the collated data are obtained at the nearest neighbour without 
interpolation nor artificial increase of the resolution. Satellite images are analysed on the basis of the index coverage of available data in the nearshore areas of the Sea of Iroise. A selection of three images is retained for the period of interest illustrating the evolution of SST patterns: in spring (on 25 May 2011), in summer (on 30 August 2011) and in autumn (on 28 September 2011).

\subsection{Model description}

The numerical model couples the Simulating WAves Nearshore (SWAN) module (Booij et al., 1999) with the 3D COupled Hydrodynamical-Ecological module for REgioNal and Shelf seas (COHERENS) (Luyten et al., 1999). COHERENS solves temperature and salinity transport equations. The principal model assumptions are placed on the 3D circulation module. The flow is assumed to be turbulent over a featureless rough bottom characterized by the roughness parameter $z_{0}$ defined as the height above the seabed at which the fluid velocity is zero.

\subsection{1. $S W A N$}

SWAN solves the time-dependent spectral action balance equation (Booij et al., 1999). Its accounts for depth shoaling, refraction, non-linear transfer of energy through wavewave interactions and wave-energy dissipation due to whitecapping, bottom friction and depth-induced breaking. The parameterizations adopted for sources and sinks are briefly detailed hereafter. Wave growth by wind is computed with the exponential term of Komen et al. (1984). Processes of whitecapping are described with the pulse-based equation of Hasselmann (1974). Energy dissipation in random waves due to depthinduced breaking is quantified according to Battjes and Janssen (1978). Finally, the empirical model of Hasselmann et al. (1973) parametrizes the sink term of bottom friction. The wave action balance equation is expressed in a spherical coordinate system. Further details about the mathematical expressions of sources and sinks are available in SWAN technical documentation (SWAN team, 2009).

\subsubsection{COHERENS}

COHERENS solves (i) the continuity equation and the Reynolds-averaged momentum equations derived using the Boussinesq's $(1877,1903)$ approximations and the vertical hydrostatic equilibrium and (ii) the 3D transport equations of temperature and salinity. The water density is computed with the general equation of state defined by the Joint Panel on Oceanographic Tables and Standards (UNESCO, 1981). The horizontal eddy viscosity $\nu_{H}$ and diffusivity $\lambda_{H}$ are parametrized following Smagorinsky (1963). The vertical eddy coefficients are expressed as $\nu_{T}=S_{u} k^{2} / \epsilon+\nu_{b}$ and $\lambda_{T}=S_{b} k^{2} / \epsilon+\lambda_{b}$ where $k$ is the turbulent kinetic energy, $\epsilon$ is its dissipation rate and $S_{u}$ and $S_{b}$ are the stability functions. These turbulent moments are obtained following Luyten et al. (1996) and Luyten (1996) by solving a one-equation $k-\epsilon$ closure scheme. A transport equation is solved for the turbulent kinetic energy $k$ while the dissipation rate is parametrized according to $\epsilon=\epsilon_{0} k^{3 / 2} / l$ where $\epsilon_{0}=0.108^{3 / 4}$ and $l$ is the mixing length computed from the formulation proposed by Blackadar (1962). $S_{u}$ and $S_{b}$ are expressed as a function of the stability parameter $\alpha_{N}=k^{2} / \varepsilon^{2} N^{2}$ where $N^{2}$ is the squared buoyancy. Finally, the background coefficients are taken equal to $\nu_{b}=\lambda_{b}=10^{-6} \mathrm{~m}^{2} \mathrm{~s}^{-1}$. 
Coupling with the wave propagation module consists in integrating waves-induced roughness in surface and bottom boundary conditions of momentum and turbulent equations. Boundary conditions are derived from the law of the wall relying on appropriate formulations of sea-surface and apparent bottom-roughness parameters denoted $z_{0 s, \omega}$ and $z_{0 b, \omega}$, respectively. Waves effects on sea-surface roughness are computed following the parameterization scheme proposed by Pan et al. (2008)

$$
\ln \left(\frac{z_{0 s, \omega}}{H_{s}}\right)=2.82 \ln \left(\frac{u_{* s}}{c_{p}}\right)-0.295
$$

where $H_{s}$ is the significant wave height and $c_{p}$ is the phase velocity of waves at peak period. The surface friction velocity $u_{* s}$ is obtained by specifying the surface stress as a function of the wind velocity $\left|u_{10}\right|$ at a reference height of $10 \mathrm{~m}$ above the sea surface

$$
\tau_{s}=\rho_{a} u_{* s}^{2}=\rho_{a} C_{D}^{s}\left|u_{10}\right|^{2}
$$

where $\rho_{a}$ is the air density taken equal to $\rho_{a}=1.2 \mathrm{~kg} \mathrm{~m}^{-3}$ and $C_{D}^{s}$ is the surface drag coefficient given by the law-of-the-wall relationship

$$
C_{D}^{s}=\left(\frac{0.4}{\ln \left(10 / z_{0 s, \omega}\right)}\right)^{2}
$$

Waves effects on bottom roughness are computed on the basis of Signell et al.'s (1990) formulation adapted from the original theory of Grant and Madsen (1979) on the interactions between wave and current bottom boundary layers. This formulation has been modified in COHERENS according to Liang et al. (2008) by introducing the effects of the random wave field and the angle $\phi_{c \omega}$ between the current and wave propagation directions. The apparent bottom roughness parameter felt by the current above the wave boundary layer is thus expressed as

$$
z_{0 b, \omega}=\delta_{\omega}^{\left|1-\frac{u_{* c}}{u_{* c \omega}}\right|} z_{0}^{\left|\frac{u_{* c}}{u_{* c \omega}}\right|}
$$

where $\delta_{\omega}=2 \kappa u_{* c \omega} / \omega$ is the thickness of the wave boundary layer, $\kappa$ is the von Karman's constant taken equal to $\kappa=0.4$ and $\omega$ is the wave frequency at the bottom wave period. The friction velocity $u_{* c \omega}$ arising from the combined wave and current shear stresses is given by

$$
u_{* c \omega}=u_{* \omega}\left[1+2\left(\frac{u_{* c}}{u_{* \omega}}\right)^{2}\left|\cos \phi_{c \omega}\right|+\left(\frac{u_{* c}}{u_{* \omega}}\right)^{4}\right]^{1 / 4} .
$$

$u_{* \omega}$ is the shear velocity associated with the wave and given by $u_{* \omega}=\sqrt{\frac{1}{2} f_{\omega}} U_{\omega}$ where $f_{\omega}$ is the wave friction factor evaluated with the empirical relations proposed by Signell et al. (1990) and $U_{\omega}$ is the wave bottom orbital velocity issued from the wave propagation module. $u_{* c}$ is the shear velocity arising from the current alone and computed assuming a vertical logarithmic profile with (i) the value of the current at the first vertical $\sigma$-grid cell above the bottom and (ii) $z_{0 b, \omega}$.

Surface boundary conditions of temperature assume that the solar radiation $Q_{s o l}$ is absorbed in the upper parts of the water column. At the sea surface, the infra-red and 
short-wave components of solar irradiance are thus equal taking the value of the solar radiation. $Q_{\text {sol }}$ is computed following Rosati and Miyakoda (1988) and Luyten et al. (1999) using the correction of clear-sky value derived by Reed (1977) to account for the cloud coverage and for the reflection by the ocean surface. Non-solar contributions $Q_{n s o l}$ of (i) latent and (ii) sensible heat fluxes and (iii) net long-wave radiation are computed following Gill (1982) and Luyten et al. (1999). Formulations of solar and non-solar heat fluxes involve the 10-m wind components, air temperature, relative humidity and fractional cloud cover. The surface salinity flux is determined using the formula proposed by Steinhorn (1991) involving the precipitation rate. Finally, the bottom boundary conditions for temperature and salinity are obtained by considering a zero flux normal to the seabed.

The set of equations is expressed in a spherical- $\sigma$ coordinate system. Further details about the circulation module are given by Luyten et al. (1999) and Guillou (2007).

\subsubsection{Numerical methods}

The wave spectral action balance equation is solved on a regular staggered grid, a constant directional resolution and an exponential frequency distribution with an implicit time discretization Euler technique. Further details about the boundary conditions and the numerical schemes are available in SWAN technical documentation (SWAN team, 2009). COHERENS circulation and transport equations are solved on a regular staggered grid with numerical schemes for time and space discretizations issued from the standard version of the code (Luyten et al., 1999). Two main modifications have been implemented. The first modification is associated with forcings of free surface and currents at the open boundaries. Mean velocities are imposed with an iterative scheme which minimizes wave reflection (Flather, 1976). The three-dimensional velocities normal to the open boundaries are imposed with the help of a simple radiation condition (Blumberg and Mellor, 1987). Further details on this modification are available in Guillou (2007) and Guillou et al. (2009). The second modification deals with the computations of sea-surface and bottom roughnesses (section 2.2.2). An iterative procedure is implemented to ensure the convergence of sea-surface roughness predictions in Eqs. 1 to 3. Computation of apparent bottom roughness $z_{0, b \omega}$ is realised on the basis of the following scheme. $u_{* \omega}$ is first computed with waves parameters issued from SWAN. $u_{* c}$ is then obtained with the estimation of $z_{0, b \omega}$ at the previous time step. Finally values of $u_{* c \omega}$ and $z_{0 b, \omega}$ are determined using Eqs. 5 and 4, respectively.

\subsection{Model setup}

The geographical domain for full computation of hydrodynamics and transport equations extends in longitude from $6^{\circ} 000 \mathrm{~W}$ to $4^{\circ} 172 \mathrm{~W}$ and in latitude from $47^{\circ} 670 \mathrm{~N}$ to $48^{\circ} 822 \mathrm{~N}$ (Fig. 1). It is discretized on a $124 \times 129$ horizontal grid with a spacing of $1 \mathrm{~km}$.

SWAN is set up on this computational domain adopting the parameterization of Guillou and Chapalain (2010) in the eastern English Channel. The wave propagation module runs with 30 exponentially spaced frequencies ranging from $0.05 \mathrm{~Hz}$ to $1 \mathrm{~Hz}$, 60 evenly spaced directions $\left(6^{\circ}\right.$ resolution) and a time step of $5 \mathrm{~min}$. The bottom friction coefficient is set to $C_{J O N}=0.038 \mathrm{~m}^{2} \mathrm{~s}^{-3}$ (Bouws and Komen, 1983). Wind velocity components at $10 \mathrm{~m}$ above the free surface are provided by the meteorological 
model ALADIN ("Aire Limitée, Adaptation dynamique, Développement InterNational", Bénard, 2004, Météo-France). The wave module is driven by global WaveWatch III (WWIII) predictions of the National Oceanic and Atmospheric Administration (NOAA) (http://polar.ncep.noaa.gov/waves). ALADIN surface and WWIII lateral boundary conditions given every three hours are interpolated at all grid points and every computational time steps. SWAN is run over the years 2010 and 2011 to extend the comparison of numerical results with measurements at offshore station WB2 (section 2.1.1).

COHERENS is implemented on the same domain with 10- $\sigma$ vertical-grid cells refined near the bottom and the surface. The time steps for external barotropic and internal baroclinic modes are $10 \mathrm{~s}$ and $100 \mathrm{~s}$, respectively. The bottom roughness associated with the seabed is determined on the basis of maps established by sedimentologists in the nearshore areas of the Sea of Iroise over computational domain \# 2 (e.g., Hinschberger et al., 1968; Chassé and Glémarec, 1976; SHOM, 1996) (Fig. 2). Values are imposed according to observations for different bottom types compiled by Soulsby (1983). The bottom roughness parameter is thus set to $z_{0}=0.2 \mathrm{~mm}$ over mud deposits and $z_{0}=$ $0.4 \mathrm{~mm}$ over sand deposits in the bays of Douarnenez, Brest and Audierne as well as in

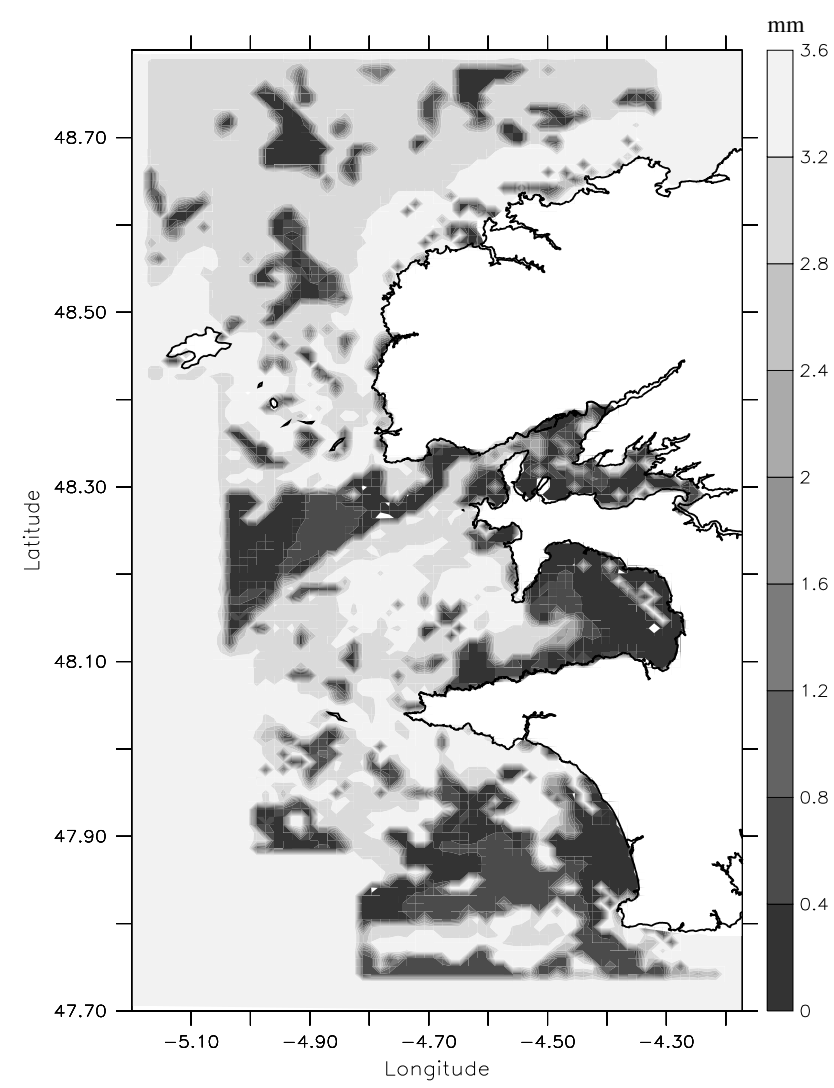

Figure 2: Spatial heterogeneous bottom roughness parameter associated with the granulometric distribution of seabed sediments in computational domain \#2. 
the south-western areas which extends from the offshore boundary till the coastline in the north of Le Conquet. The roughness parameter takes the value of $z_{0}=3 \mathrm{~mm}$ in regions of gravel and $z_{0}=3.5 \mathrm{~mm}$ over rocky outcrops located in the north of computational domain \#2, off the Crozon peninsula and in the north-western part of the bay of Audierne till the isle of Sein. The offshore bottom roughness is set to an uniform value of $z_{0}=3.5 \mathrm{~mm}$ as implemented by Muller et al. (2007). The circulation module is driven by free-surface elevation and depth-averaged currents predicted by the operational Iberian Biscay Irish (IBI) Ocean Analysis and Forecasting system and delivered at one-hour interval and a 3 km-spatial resolution by MyOcean project (http://www.myocean.eu). Benefits of using IBI hydrodynamic boundary conditions are the integration of surges and geostrophic velocities in addition to tide effects. Outflows at the mouth of rivers Elorn and Aulne in the bay of Brest (Fig. 1) are derived from measurements at two upstream stations (http://www.hydro.eaufrance.fr). Finally, ALADIN surface data of wind speed and atmospheric pressure and SWAN outputs are imposed at three-hours intervals in the circulation module.

IBI forecasts are also used to provide daily-averaged vertical profiles of temperature and salinity along maritime open boundaries. Surface heat fluxes are computed with parameters of 10-m wind components, air temperature, relative humidity and fractional cloud coverage given at three-hours intervals by ALADIN meteorological model. The precipitation rate is taken spatially-uniform and obtained from the database of the National Centers for Environmental Predictions (NCEP) (http://www.esrl.noaa.gov/ psd/data). Temperature boundary conditions at the rivers mouth are supplied by measurements at water treatment stations.

COHERENS is run over the period from April to October 2011 as IBI data were provided since April 2011 by MyOcean project and SIRANO observations were available till October 2011 (section 2.1.1). In order to investigate the effects of bottom roughness on SST predictions, three numerical experiments are conducted considering successively (i) an uniform bottom roughness parameter taken equal to $z_{0}=0.0035 \mathrm{~m}$ as integrated by Muller et al. (2007) (experiment A), and the heterogeneous roughnesses associated with (ii) the granulometric distribution of seabed sediments displayed in Fig. 2 (experiment B) and (iii) the superimposed effect of the wave in the bottom boundary layer (experiment $\mathrm{C}$ ) (Table 2). The three numerical experiments are compared with the standard statistical parameters of the maximum difference and the average of the absolute differences MABS of the SST given by the following relationship

$$
\text { MABS }=\frac{1}{N} \sum_{i=1}^{i=N} \operatorname{MABS}_{i}
$$

with

$$
\operatorname{MABS}_{i}=\left|T_{i}^{\alpha}-T_{i}^{\beta}\right|
$$

where $T_{i}^{\alpha}$ and $T_{i}^{\beta}$ represent the two sets of measured or simulated SST data $\alpha$ and $\beta$ for $i \in[1, N] . N$ refers alternately to the number of data in computational domain or in time series whether the analysis focuses on the spatial or temporal variabilities of numerical predictions. 


\section{Results and discussion}

\subsection{Comparison with observations}

\subsubsection{In-situ measurements}

Predicted time series of wave height, peak period and peak direction are consistent with available measurements at station WB1 from January 2010 to September 2011 and station WB2 from January 2010 to November 2010. A close investigation is conducted on the comparison with measurements at station WB1 as observations were available at this point during the period of interest from April to September 2011 (Fig. 3). In spite of a slight overestimation around $5-10 \%$ of the significant wave height, the model reproduces fairly well the magnitude of the storms heights reaching values over $4 \mathrm{~m}$ in May, June and July 2011. The numerical results approach also the observed variations of the wave peak period and direction.

The comparison of SST numerical results and in-situ measurements is conducted on the basis of predictions for the most complete simulation titled experiment $\mathrm{C}$ (Table 2 ). Predictions are in agreement with observations along the averaged SIRANO vessel path from April to October 2011 (Fig. 4). The model reproduces the observed seasonal evolution of SST with increases in summer by $2{ }^{\circ} \mathrm{C}$ of offshore waters around the isles of Ushant and Molène (points \#1 to \#3) reaching $3{ }^{\circ} \mathrm{C}$ in nearshore waters (points \#4 and $\# 5$ ) and $5{ }^{\circ} \mathrm{C}$ at the entrance of the bay of Brest (point \#6). Whereas predictions tend to underestimate by $0.5-1{ }^{\circ} \mathrm{C}$ measurements in spring and autumn, differences are lessening in summer at points \#1 to \#5. Numerical results tend, however, to overestimate SST
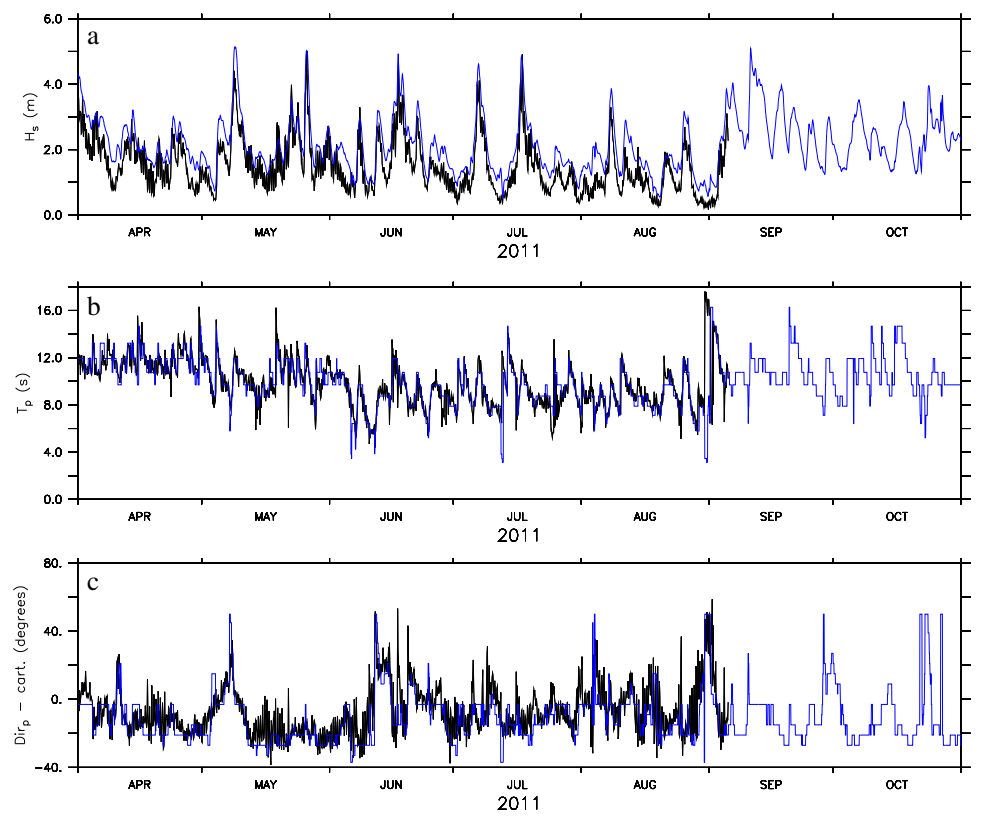

Figure 3: Measured (black line) and computed (blue line) time series of (a) the significant wave height, (b) the peak period and (c) the peak direction (anticlockwise from the East) at station WB1 from April to October 2011. 
at point \#6. This tendency is particularly noticeable in July and August 2011 when the maximum difference is reaching $1.5^{\circ} \mathrm{C}$. Whereas the $1 \mathrm{~km}$-spatial resolution may be too large for a precise approach of water mass and temperature exchanges between the bay of Brest and the Sea of Iroise, the present configuration approaches the main offshore SST patterns while avoiding prohibitive demand on computer computational time and memory. Numerical predictions reproduces thus fairly well the daily and bi-monthly SST variations exhibited at fixed-point stations WB1 and WB2 from April to September 2011 (Fig. 5). Daily changes in SST characterized the night-day cycle. Bi-monthly variations appear to result from the strength of the tide with reduced SST during spring and increased SST during neap tidal cycles (Fig. 6). These results confirm the well-known significance of the tide on temperature vertical mixing in the Sea of Iroise (e.g., AltazinPichon, 1981; Mariette et al., 1982; Mariette, 1983; Mariette and Le Cann, 1985). These SST variations are however difficult to capture with SIRANO observations in relation to the weak number of data per day (section 2.1.1).

\subsubsection{Satellite images}

SST time series derived from remote-sensing data are consistent with in-situ measurements at nearshore (Fig. 4) and offshore (Fig. 5) locations in spite of a slight underestimation of observed values by $0.5^{\circ} \mathrm{C}$ in spring and autumn. These comparisons show the benefit of extending the analysis of numerical prediction through a confrontation with satellite images. An overall good agreement is obtained between observations and predictions of SST spatial patterns during the period of interest, from April to October 2011 (Fig. 7). In spring (Fig. 7-a), the modelling system reproduces fairly well the warming of surface waters along the southern boundary where tidal currents and associated mixing are too weak to stand in the way of vertical stratification (Le Cann, 1982). Numerical results approach also the warming of surface waters in the nearshore areas of the bay of Douarnenez where remote sensing data are available. In summer (Fig. 7-b), predictions exhibit clearly the development of a region of intense vertical mixing from the northern boundary till the south-western extend of the reef of Sein. This area characterized by weak SST below $14{ }^{\circ} \mathrm{C}$ has been identified by numerous scientific studies (e.g., Pingree et al., 1977; Mariette and Le Cann, 1985; Le Boyer et al., 2009). This thermal structure is associated with the development of two horizontal thermal fronts, (i) the former, denoted the Ushant front, appearing a few kilometres off the isle of Ushant till the reef of Sein (Pingree et al., 1977; Mariette and Le Corre, 1982), (ii) the latter, creating at the verge of the system made by the bays of Douarnenez and Brest (e.g., Muller et al., 2007). The modelling system approaches fairly well the associated horizontal thermal gradient of around $4{ }^{\circ} \mathrm{C}$ in less than $2 \mathrm{~km}$. Nevertheless, SST tends to be overestimated in the nearshore areas of the bays of Brest and Douarnenez, as well as in the intermediate region between the two cold predicted areas around the isle of Ushant and near the reef of Sein. These differences may be associated with the difficulty to represent vertical mixing in most ocean circulation models in relation to parameterizations of turbulence closure schemes and surface roughness (Lopes et al., 2009; Renaudie et al., 2011). These differences attributed to underestimated vertical mixings are however lessening in autumn (Fig. 7-c). SST is thus found to be overestimated by $0.5-1{ }^{\circ} \mathrm{C}$ over these areas in 28 September 2011. The global comparison with satellite images confirms the capability of the model predictions to reproduce the major SST patterns appearing from spring till autumn 2011 in the Sea of Iroise. 

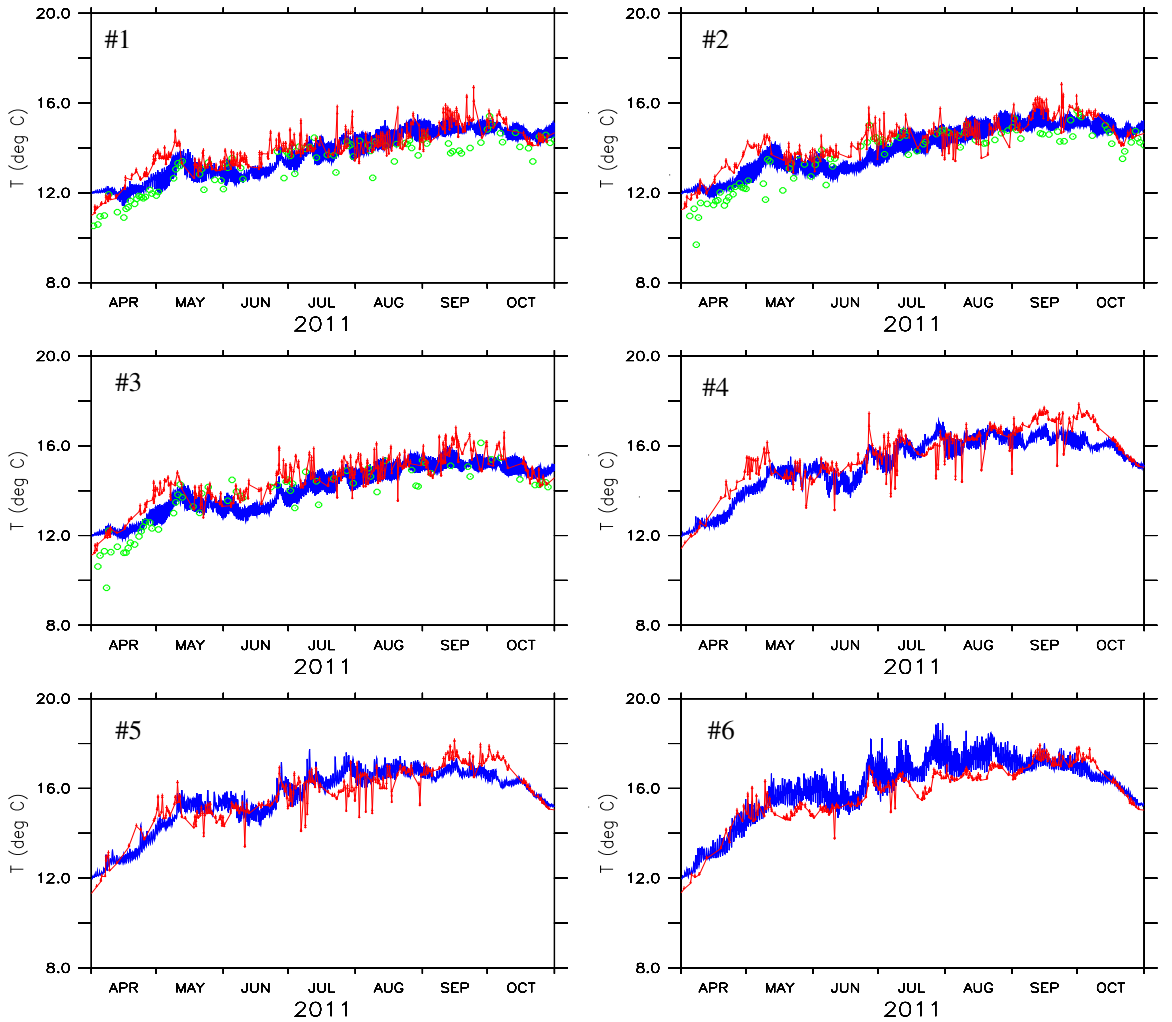

Figure 4: Measured (red lines) and computed from experiment C (blue lines) time series of SST at points \#1 to \#6. Green circles show SST at points \#1 to \#3 derived from satellite observations.
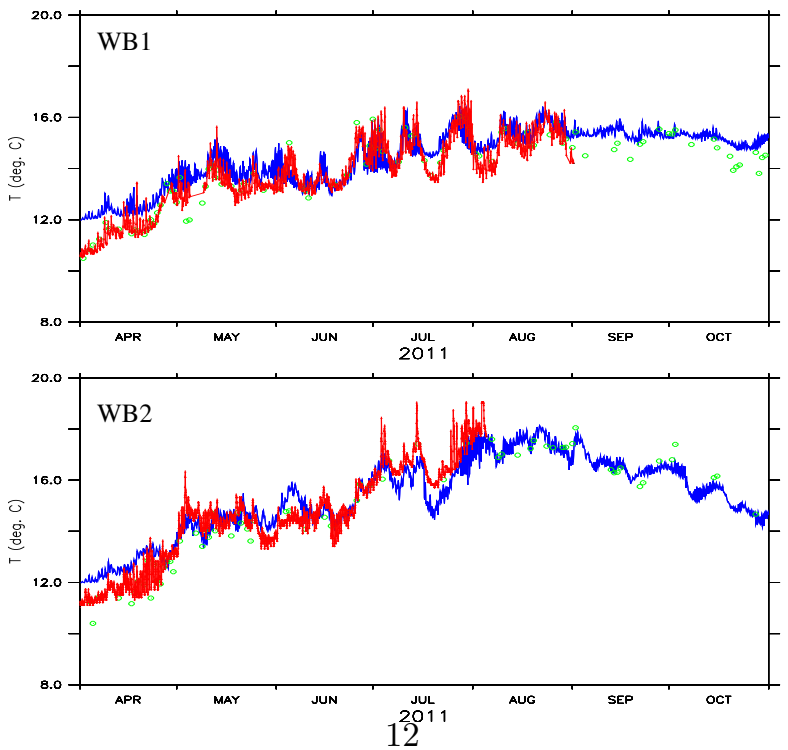

Figure 5: Measured (red lines) and computed from experiment $\mathrm{C}$ (blue lines) time series of SST at stations WB1 and WB2. Green circles show SST derived from satellite observations. 


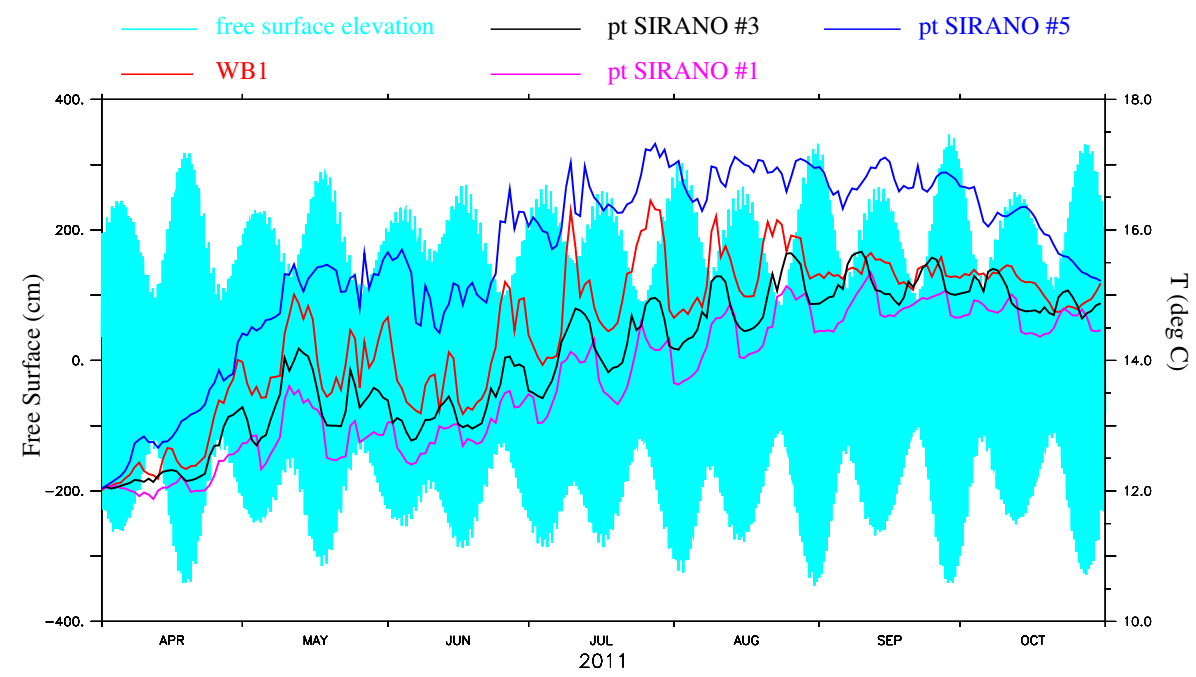

Figure 6: Predicted time series of free-surface elevation at the harbour of Brest and daily SST at station WB1 and points \#1, \#3 and \#5 (from experiment C).

\subsection{Sensitivity study}

\subsubsection{Improvements of numerical predictions}

The improvement of SST predictions reached with the three parameterizations of bottom roughness (Table 2) is analysed further. This investigation relies on SST derived from satellite images as slight differences are obtained between the three numerical experiments A, B and C at each measuring points \#1 to \#6 and WB1 and WB2. Although remote-sensing data may present biases, this analysis gives a preliminary estimation of the effects of bottom roughness on predicted SST. The comparison is conducted retaining satellite observations with more than $70 \%$ of available data in computational domain \#2 (Fig. 8-a). Numerical predictions are interpolated on the grid of remote-sensing data over the simulation domain. Finally, the average of the absolute differences between predicted and observed SST is computed for each day retained resulting in three values of MABS (Eq. 6): $\mathrm{MABS}_{A}, \mathrm{MABS}_{B}$ and $\mathrm{MABS}_{C}$ for configurations A, B and C, respectively. Fig. 8-b displays the differences $\mathrm{MABS}_{A}-\mathrm{MABS}_{B}$ over the period April-October 2011. Positive values in Fig. 8-b show the improvement obtained in the estimation of SST derived from satellite images by integrating a heterogeneous bottom roughness distribution associated with the granulometric distribution of seabed sediments. The bottom roughness parameterization is found to have an impact on SST numerical estimates in the nearshore areas of the Sea of Iroise for the period of simulation. The implementation of a semi-realistic heterogeneous-seabed roughness is thus improving globally SST predictions in spite of local increased differences in summer and autumn.

Differences are exhibited with the superimposed effect of waves in the bottom boundary layer. Fig. 8-c shows the differences $\mathrm{MABS}_{A}-\mathrm{MABS}_{C}$ over the period of interest. Increase of the apparent bottom roughness has a non-negligible effect on SST numerical estimates highlighting differences during storm events of May, July and September 2011. The combined integration of an heterogeneous seabed roughness and waves in the bottom 

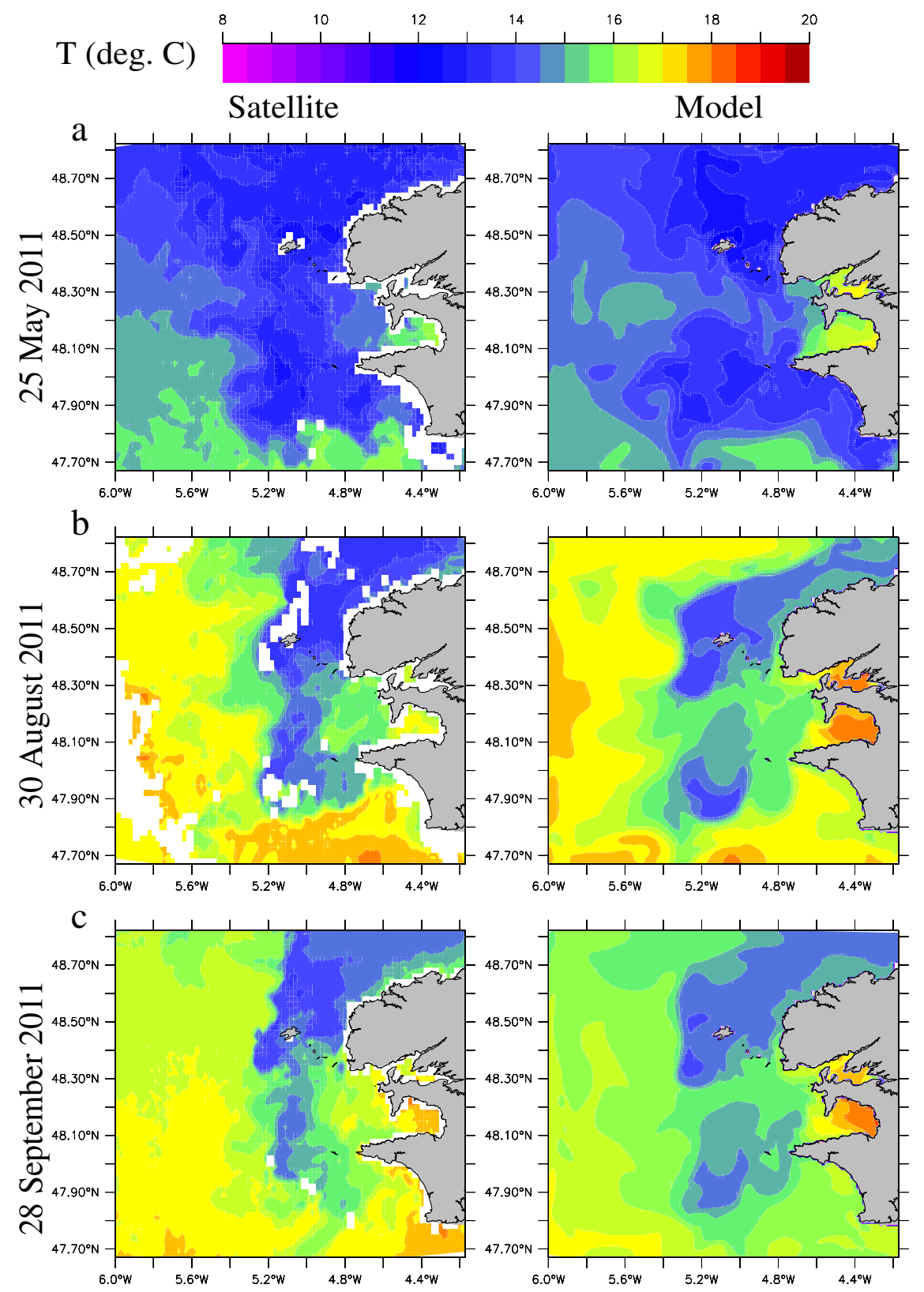

Figure 7: Observed (left) and computed from experiment C (right) SST on (a) 25 May, (b) 30 August and (c) 28 September 2011. Clouds (blank data) appear as white patches on remote sensing images. 


\begin{tabular}{|c|c|c|c|}
\hline \multirow{3}{*}{$\begin{array}{l}\text { Numerical } \\
\text { experiments }\end{array}$} & & \multicolumn{2}{|c|}{ Bottom roughness } \\
\hline & \multirow{2}{*}{$\begin{array}{c}\text { Uniform } \\
z_{0}=3.5 \mathrm{~mm}\end{array}$} & \multicolumn{2}{|c|}{ Heterogeneous } \\
\hline & & $\begin{array}{c}\text { Seabed } \\
\text { distribution }\end{array}$ & $\begin{array}{l}\text { Wave } \\
\text { effect }\end{array}$ \\
\hline A & Yes & No & No \\
\hline B & No & Yes & No \\
\hline $\mathrm{C}$ & No & Yes & Yes \\
\hline
\end{tabular}

Table 2: List of numerical experiments for the circulation and transport modules COHERENS.
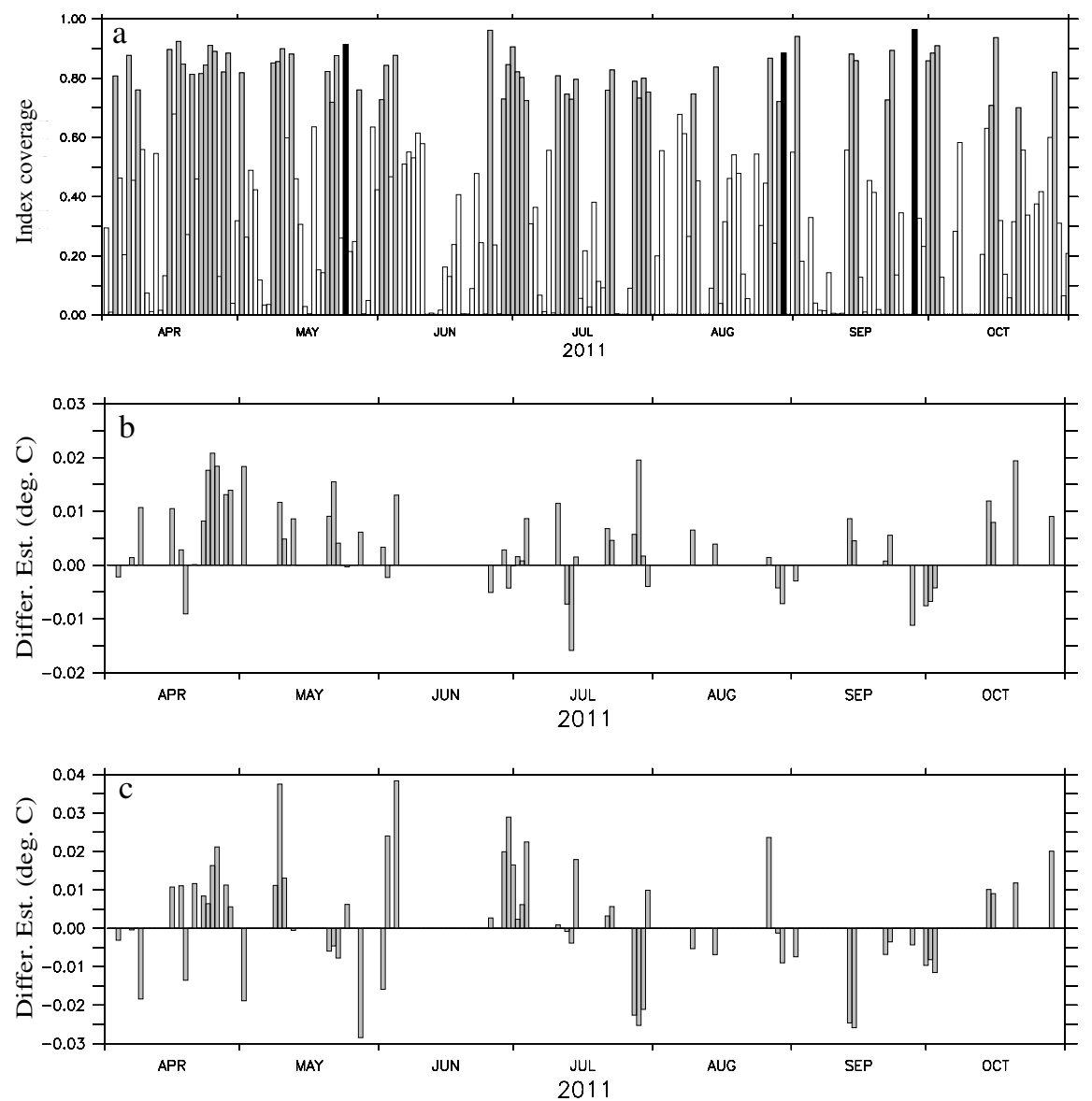

Figure 8: (a) Index coverage of SST satellite data in computational domain \#2. Days when the index coverage is over $70 \%$ are displayed with light-grey bars. Days selected in Fig. 7 are showed with black bars. (b and c) Differences in the averaged absolute estimation of SST observed by satellite between configurations (a) B and A and (b) C and A. Positive values indicate an improved estimation of SST with simulations (a) B and (b) C, respectively. 
boundary layer (case C) is also leading to global enhancement of SST predictions. Nevertheless the averaged improvement over the period April-October 2011 is weaker in case $\mathrm{C}$ than in case B. The histogram area is thus reducing from $0.26{ }^{\circ} \mathrm{C}$ in Fig. 8-b to $0.13{ }^{\circ} \mathrm{C}$ in Fig. 8-c. Numerical results in case $\mathrm{C}$ may improve with additional parameterizations of the apparent roughness and the associated thickness of the wave boundary layer (e.g., Soulsby et al., 1993; Zhang et al., 2004). In the present investigation, the formulations here retained are considered to approach the overall effect of waves roughness on SST in the Sea of Iroise.

\subsubsection{SST spatial and temporal variabilities}

Numerical predictions are exploited further to analyse the variability of SST in computational domain \#2 where the heterogeneous bottom roughness parameterizations are introduced. The investigation is conducted over the period July-September 2011 when horizontal thermal gradients are well developed (e.g., Le Boyer et al., 2009). Figs. 9-A1 and 9-A2 display the maximum differences and the average of the absolute differences between SST predicted with configurations B and A. These results confirm the negligible influence of the seabed roughness distribution on SST predicted along the route of the vessel path. The maximum difference lies below $0.2{ }^{\circ} \mathrm{C}$ for the period considered in this area (Fig. 9-A1). Main differences are obtained offshore at the north-western and south-western edges of the external thermal front of Ushant with maximum SST changes over $1{ }^{\circ} \mathrm{C}$. Indeed, these two offshore regions are found to be the most sensible to the bottom roughness parameterization as being characterized by significant tidal hydrodynamic regimes (e.g., SHOM, 1968) and partially-mixed vertical-temperature profiles. Secondary differences are obtained nearshore (i) in the south of the bay of Douarnenez and (ii) in the south-eastern part of the bay of Brest. Both regions are characterized by strong-predicted horizontal-thermal gradients (Fig. 7). The region identified in the bay of Douarnenez is thus located at the interface between warm coastal and cold offshore surface waters. The superimposed effect of waves on predicted SST is displayed in Figs. 9-B1 and 9-B2 with the maximum differences and the average of the absolute differences between SST predicted with configurations $\mathrm{C}$ and A. Waves appear to have an impact on SST (i) in the bay of Audierne and (ii) off the southern part of Crozon peninsula with maximum differences in predicted SST over $1{ }^{\circ} \mathrm{C}$. The averaged difference reaches also its maximum value of $0.2{ }^{\circ} \mathrm{C}$ off Crozon peninsula. These results are explained by the significant exposure of these two regions to the incident waves in the Sea of Iroise. Waves are thus appearing to modulate the SST in the intermediate thermal region located between the two cold predicted areas around the isle of Ushant and the reef of Sein.

The temporal variability of predicted SST is analysed further off Crozon peninsula at location $\mathrm{t}_{1}$ (Fig. 9-B1, $\lambda=4.60^{\circ} \mathrm{W}, \phi=48.20^{\circ} \mathrm{N}$ ) where the effects of waves on simulations have been exhibited. The local evolution of predicted SST presents major changes in conditions of combined (i) spring-tide and moderate waves and (ii) storm waves (Figs. 10 and 11-a). Predictions are slightly influenced by the integration of the heterogeneous bottom roughness associated the grain-size of seabed sediments. Nevertheless, the superimposed effect of waves is found to increase SST by more than $1{ }^{\circ} \mathrm{C}$ during spring-tide conditions of mid-August 2011. This analysis is extended by averaging the differences over computational domain \#2. Fig 11-b displays the time series of the average of the absolute differences between SST predicted with configurations B and A. This evolution 
(deg. C.)
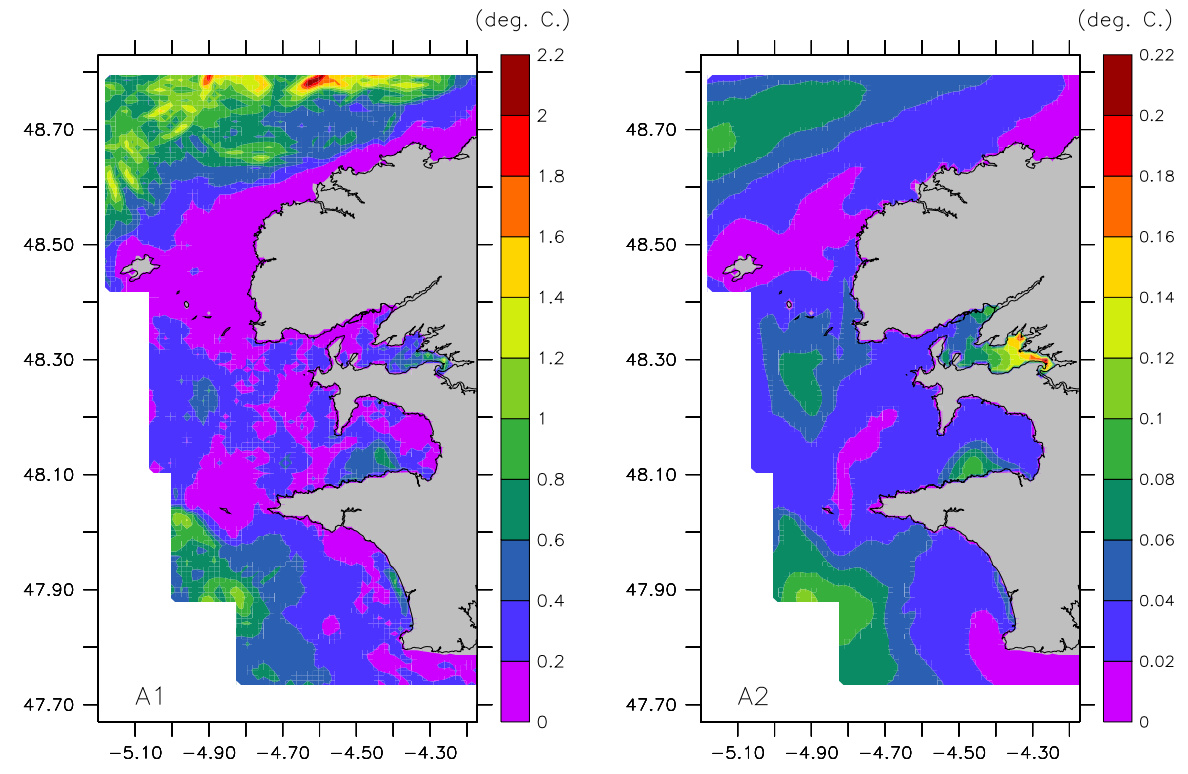

Maximum differences

Aver. abs. differences
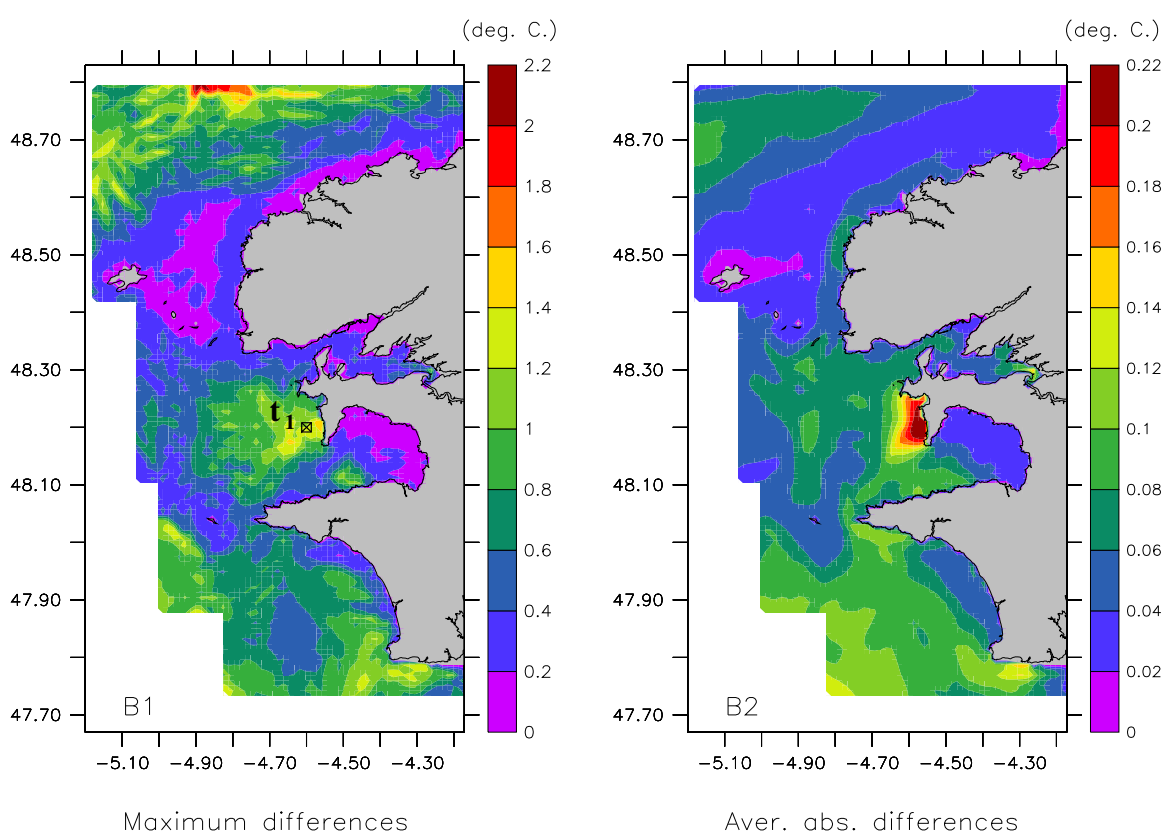

Figure 9: Maximum differences and average of the absolute differences between SST predicted with configurations (A1-A2) B and A and (B1-B2) C and A from July to September 2011. The black square in Fig. B1 shows the location where the SST evolution is analysed further in Fig. 10. 
of the averaged difference is characterized by spring-neap tide modulations with maximum values obtained during spring tides. The significance of the tide on temperature gradients in the Sea of Iroise (section 3.1.1) explains these modulations. Indeed, changes in bottom roughness modify the bottom friction associated with the tide thus impacting the vertical mixing of temperature and the resulting SST. This effect is stronger for strong bottom constraints obtained during spring tides. Differences are naturally exhibited for highest horizontal thermal gradients developing in spring and summer in the Sea of Iroise (June, July and August 2011). The superimposed effect of the waves in the bottom boundary layer globally increases these differences as the apparent bottom roughness is increasing. The time series of the average of the absolute differences in computational domain \#2 between predictions issued from configurations $\mathrm{C}$ and $\mathrm{A}$ is still characterized by spring-neap tide modulations. This periodicity tends however to lessen during highest storm events of early May and June, mid-July and September 2011.

\section{Conclusions}

A 3D hydrological model based on the coupling of COHERENS circulation and SWAN wave propagation modules has been implemented in the Sea of Iroise to investigate the effects of the heterogeneous seabed roughness and the wave in the bottom boundary layer on SST predictions. Numerical results have been compared with in-situ measurements at fixed-point stations and along the route of a vessel travelling between the coast and the isle of Ushant. This comparison has been extended to SST derived from satellite images. The main outcomes of the present study are the following.

(1) Numerical predictions reproduce the observed seasonal, spring-neap tide and daynight evolutions of SST in the nearshore areas of the computational domain as well as major spatial SST patterns characterizing the evolution of thermal gradients in the Sea of Iroise. Theses comparisons confirm the significance of the tide in the development of horizontal thermal gradients and vertical stratification in the nearshore areas.

(2) The sensitivity study exhibits the effect of bottom roughness parameterizations on SST predictions. The integration of a heterogeneous bottom roughness distribution is found to improve slightly the numerical estimates of SST. These results are not so well established with the superimposed effect of the waves on the bottom roughness. Nevertheless, its integration is also leading to global improvements of numerical predictions.

(3) The consequences of these parameterizations on spatial and temporal variabilities of predicted SST are analysed further. Mappings of the differences in SST predicted with the different formulations are produced in the nearshore areas of the Sea of Iroise. Sensitivity of numerical predictions is noticeably exacerbated in regions of high thermal gradients. While the heterogeneous bottom roughness distribution is found to have a major impact at the edge of the Ushant thermal front, waves appear to increase mixing of temperature in the nearshore areas of the bay of Audierne and the western extend of Crozon peninsula.

The present study provides thus interesting insights into the evolution of SST in the nearshore areas of the Sea of Iroise. Available in-situ measurements sites appear however to be minimally impacted by the different parameterizations of bottom roughness 

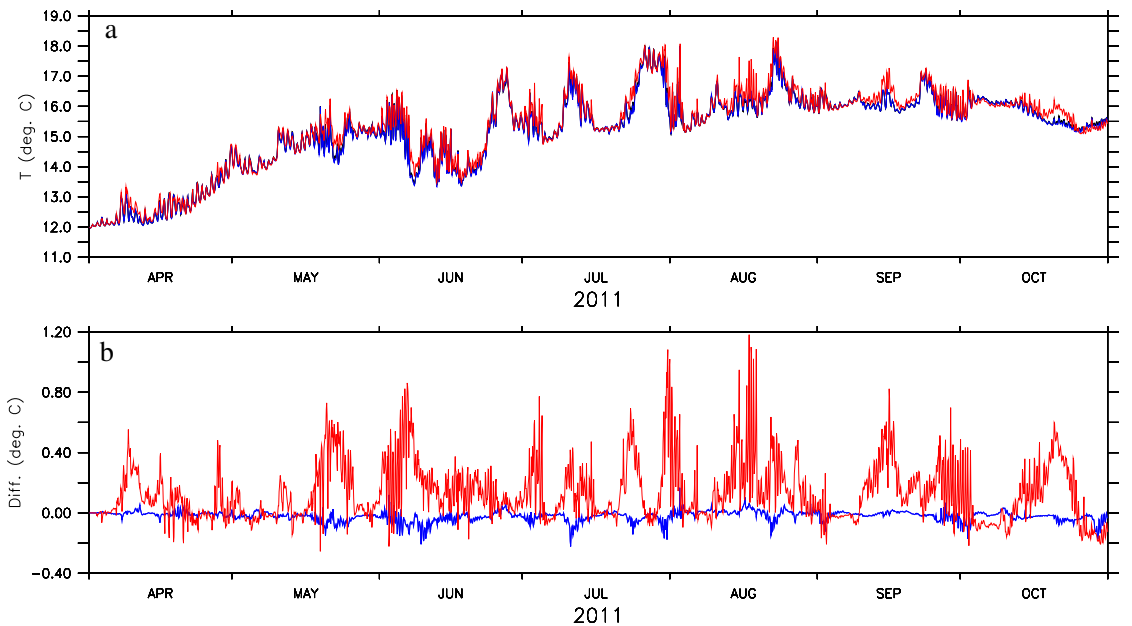

Figure 10: Time series of (a) the SST predicted from configurations B (blue line) and C (red line) and (b) the differences between SST predicted from configurations B and A (blue line) and C and A (red line) at location $\mathrm{t} 1$.
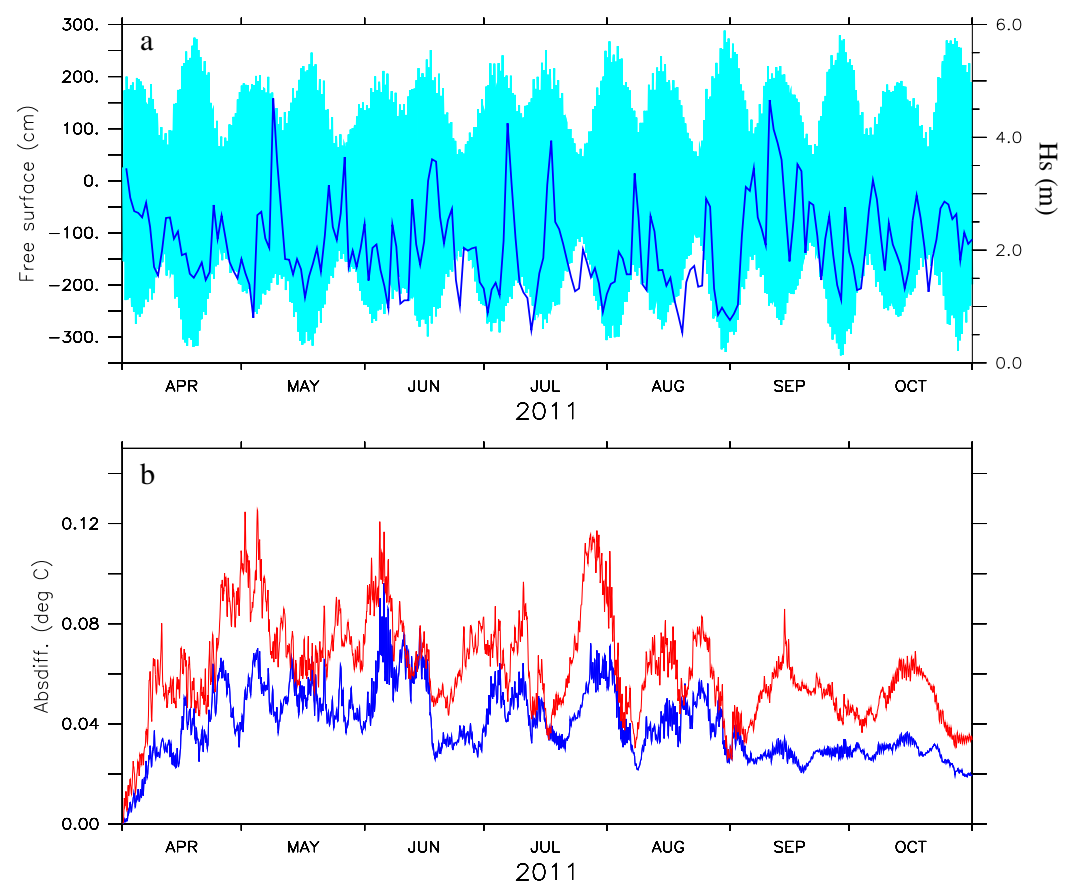

Figure 11: (a) Time series of the free-surface elevation (blue light) and the significant wave height (blue dark) at point of coordinates $\left(\lambda=4.80^{\circ} \mathrm{W}, \phi=48.20^{\circ} \mathrm{N}\right)$ located in the center of computational domain \#2. (b) Time series of the average over computational domain \# 2 of the absolute differences between SST predicted in configurations B and A (blue line) and C and A (red line). 
implemented. A prospective of this research will consist in refining the comparison with complementary SST observations realized in the bay of Audierne and in the intermediate area of horizontal thermal gradients off Crozon peninsula. These results promote the integration of an heterogeneous bottom roughness distribution over the whole computational domain relying on complementary observations of bottom substrate. Furthermore, the comparison could be extended to additional observed parameters derived from SIRANO project like the surface salinity, turbidity or chlorophyll-a fluorescence. These developments will aim at an improved numerical hydrological application of high concerns for water quality purposes in the Sea of Iroise.

\section{Aknowledgments}

The authors are grateful to the MyOcean (European Commission) project for providing numerical predictions of the operational Iberian Biscay Irish Ocean Analysis and Forecasting system and remote sensing observations of SST derived from the European Ocean-Sea Surface Temperature MultiSensor L3. Météo-France supplied measurements of wave parameters and SST at offshore stations as well as wind fields and surface heat fluxes obtained with the meteorological model ALADIN. The authors warmly thank "le conseil général du Finistère" and "Brest Métropole Océane" for the financial support of the SIRANO project, as well as the shipping company "Penn ar Bed" for providing access aboard "Enez Eussa III" vessel. Simulations were performed on computer facilities CAPARMOR ("CAlcul PARallèle Mutualisé pour l'Océanographie et la Recherche"). The present paper is a contribution to the research program of the Laboratory of Coastal Engineering and Environment (http://memphys-lgce.fr.ht).

\section{References}

\section{References}

Altazin-Pichon, A., 1981. Application d'un modèle de thermocline à la formation du front thermique en mer d'Iroise. Confrontation des résultats avec des mesures in situ. Doctoral Thesis, Université de Bretagne Occidentale, Brest, 140 pp.

Augris, C., Ménesguen, A., Hamon, D., Blanchet, A., Le Roy, P., Rolet, J., Jouet, G., Véron, G., Delannoy, H., Drogou, M., Bernard, C., Maillard, X. 2005. Atlas thématique de l'environnement marin de la baie de Douarnenez (Finistère). Ifremer.

Battjes, J., Janssen, J. 1978. Energy loss and set-up due to breaking of random waves. In: Proceedings of 16th International Conference of Coastal Engineering, Hambourg, 569-587.

Bénard, P., 2004. ALADIN-NH/AROME dynamical core: status and possible extension to IFS. In: Proceedings of the ECMWF Seminar, 27-40.

Benoit, M., Lafon, F. 2004. A nearshore wave atlas along the coasts of France based on the numerical modeling of wave climate over 25 years. Coastal Engineering, 714-726.

Blackadar, A.K., 1962. The vertical distribution of wind and turbulent exchange in a neutral atmosphere. Journal of Geophysical Research, 67, 3095-3102.

Blumberg, A.F., Mellor, G.L., 1987. A description of a three-dimensional coastal ocean circulation model. In: Three-Dimensional Coastal Ocean Models, Coastal and Estuarine Sci., vol. 4, edited by N.S. Heaps, 1-16, AGU, Washington, D.C.

Booij, N.R.C., Ris, R.C., Holthuijsen, L.H., 1999. A third generation wave model for coastal regions, part i, model description and validation. Journal of Geophysical Research, 104 (C4), 7649-7666.

Boussinesq, J., 1877. Essai sur la théorie des eaux courantes. Mémoire présenté par divers savants à l'Académie des Sciences de Paris, vol. 20, Paris, pp. 380-398.

Boussinesq, J., 1903. Théorie analytique de la chaleur, mise en harmonie avec la thermodynamique et avec la théorie mécanique de la lumière. Gauthiers-Villars, Paris. 
Bouws, E., G. Komen, G., 1983. On the balance between growth and dissipation in an extreme, depthlimited wind-sea in the southern North Sea. Journal of Physical Oceanography, 13, 1653-1658.

Cambon, G., 2008. Etude numérique de la mer d'Iroise : Dynamique, variabilité du front d'Ouessant et évaluation des échanges cross-frontaux. Doctoral Thesis, Université de Bretagne Occidentale, 195 p.

Chassé, C., Glémarec, M., 1976. Atlas des fondes meubles du plateau continental du Golfe de Gascogne. Cartes bio-sédimentaires. I.C.A. Brest.

Duvieilbourg, E., Chapalain, G., Guillou, N., 2012. Observation multiparamètres par navire d'opportunités le long du continuum terre-mer de la rade de Brest et de la mer d'Iroise. XIIèmes Journées Nationales Génie Côtier - Génie Civil, Cherbourg.

Flather, R.A., 1976. A tidal model of the northwest european continental shelf. Mémoires de la Société Royale des Sciences de Liège, 97, 141-164.

Gill A.E., 1982. Atmosphere-Ocean Dynamics. International Geophysics Series, vol. 30. Academic Press, Orlando, 662 pp.

Grant, W.D., Madsen, O.S., 1979. Combined wave and current interaction with a rough bottom. Journal of Geophysical Research, 94 (C4), 1797-1808.

Grayek, S., Staneva J., Schulz-Stellenfleth, J., Petersen, W., Stanev, E.V., 2011. Use of FerryBox surface temperature and salinity measurements to improve model based state estimates for the German Bight. Journal of Marine Systems, 88, 45-59.

Guillou, N., Chapalain, G., 2010. Modelling impact of northerly wind-generated waves on sediments resuspensions in the Dover Strait and adjacent waters. Continental Shelf Research, 31, 1894-1903.

Guillou, N., Chapalain, G., Thais, L., 2009. Three-dimensional modelling of tide-induced suspended transport of seabed multicomponent sediments in the eastern English Channel. Journal of Geophysical Rsearch - Oceans, 114, C07025.

Guillou, N., 2007. Rôles de l'hétérogénéité des sédiments de fond et des interactions houle-courant sur l'hydrodynamique et la dynamique sédimentaire en zone subtidale - applications en Manche orientale et la pointe de la Bretagne. Doctoral Thesis in Physical Oceanography, Université de Bretagne Occidentale, 469 pp. (available via http://tel.archives-ouvertes.fr/tel-00376679/en/)

Hasselmann, K., 1974. On the spectral dissipation of ocean waves due to whitecapping. Boundary Layer Meteorology, 1-2 (6), 107-127.

Hasselmann, K., Barnett, T.P., Bouws, E., Carlson, H., Cartwright, D.E., Enke, K., Ewing, J.A. Gienapp, H., Hasselmann, D.E., Kruseman, P., Meerburg, A., Muller, P., Olbers, D.J., Richter, K., Sell, W., Walden, H., 1973. Measurements of wind-wave growth and swell decay during the Joint North Sea Wave Project (JONSWAP). Ergänzungsheft zur Deutschen Hydrographischen Zeitschrift Reihe A8 (12), 95 pp.

Hinschberger, F., Guilcher, A., Pruleau, M., Moign, A., Moign, Y. 1968. Carte sédimentologique sousmarine des côtes de France. Feuille de Brest. Echelle 1/100000. DGRST-CNEXO.

Komen, G.J., Hasselman, S., Hasselman, K., 1984. On the existence of a fully developed wind-sea spectrum. Journal of Physical Oceanography, 14, 1271-1285.

Le Boyer, A., Cambon, G., Daniault, N., Herbette, S., Le Cann, B., Marié, L., Morin, P., 2009. Observations of the Ushant tidal front in September 2007. Continental Shelf Research, 29, 1026-1037.

Le Cann B., 1982. Evolution annuelle de la structure hydrologique du plateau continental au Sud de la Bretagne. Modélisation numérique. Doctoral Thesis in Physical Oceanography. Université de Bretagne Occidentale, Brest, France, 252 pp.

Le Corre, P., Mariette, V. 1985. Le front thermique d'Ouessant en août et septembre 1982, Campagne SATIR-DYNATLANT. Campagnes Océanographiques Françaises, vol.1. Institut Français de Recherche pour l'Exploitation de la Mer.

Liang, B.-C., Li, H.-j., Lee, D.-y., 2008. Bottom shear stress under wave-current interaction. Journal of Hydrodynamics, 20 (1), 88-95.

Lopes, J.F., Cardoso, A.C., Moita, M.T., Rocha, A.C., Ferreira, J.A., 2009. Modelling the temperature and the phytoplankton distributions at the Aveiro near coastal zone, Portugal. Ecological Modelling, 220, 940-961.

Luyten, P. J., Jones, J. E., Proctor, R., Tabor, A., Tett, P., Wild-Aden, K., 1999. COHERENS: A COupled Hydrodynamics-Ecological model for REgioNal and Shelf seas - Model Description (Available on CD-ROM via http://www.mumm.ac.be/coherens). Management Unit of the North Sea Mathematical Models, Report MAS3-CT97-0088, Belgium, 911 pp.

Luyten, P., Deleersnijder, E., Ozer, J., Ruddick, K.G., 1996. Presentation of a family of turbulence closure models for stratified shallow water flows and preliminary application to the Rhine outflow region. Continental Shelf Research, 16, 101-130.

Luyten, P., 1996. An analytical and numerical study of surface and bottom boundary layers with variable 
forcing and application to the North Sea. Journal of Marine Systems, 8, 171-189.

Mariette, V., 1983. Effet des échanges atmosphériques sur la structure thermique marine. Application à des zones du large et à une zone côtière. Doctoral Thesis, Université de Bretagne Occidentale, Brest.

Mariette, V., Rougier, G., Salomon, J.C., Simon, B., 1982. Courants de marée en mer d'Iroise. Oceanologica Acta, 5(2), 149-159.

Mariette, V., Le Cann, B., 1985. Simulation of the formation of Ushant thermal front. Continental Shelf Research, 4, 637-660.

Mariette, V., Le Corre, P., 1982. Le front thermique d'Ouessant en août et septembre 1982, campagne Satir Dynatlant. Campagne océanographique française, n. 1-1985. IFREMER, France.

Muller, H., 2008. Etude de la circulation résiduelle langrangienne en mer d'Iroise. Doctoral Thesis, Université de Bretagne Occidentale, 209 pp.

Muller, H., Dumas, F., Blanke, B., Mariette, V., 2007. High-resolution atmospheric forcing for regional oceanic model: the Iroise Sea. Ocean Dynamics, 57 (4-5), 375-400.

Pan, Y., Sha, W., Zhu, S., Ge., S., 2008. A new parameterization scheme for sea surface aerodynamic roughness. Progress in Natural Science, 18, 1365-1373.

Petersen, W., Wehde, H., Krasemann, H., Colijn, F., Schroeder, F., 2008. FerryBox and MERIS - Assessment of coastal and shelf sea ecosystems by combining in-situ and remotely sensed data. Estuarine, Coastal and Shelf Science, 77, 296-307.

Pingree, R.D., Holligan, P.M., Head, R.N. 1977. Survival of dinoflagellate blooms in the western English Channel. Nature, 265, 266-269.

Reed, R.K., 1977. On estimating insolation over the ocean. Journal of Physical Oceanography, 7, 482-485.

Renaudié, C., Morel, Y., Hello, G., Giordani, H. and Baraille, R., 2011. Observation and analysis of mixing in a tidal and wind-mixed coastal region. Ocean Modelling. 37, 65-84

Rosati, A.N., Miyakoda, K., 1988. A general circulation model for upper ocean simulation. Journal of Physical Oceanography. 18, 1601-1626.

Service Hydrographique et Océanographique de la Marine, 1996. Nature des fonds de la Chaussée de Sein à la pointe de Penmarc'h, baie d'Audierne.1/50000. EPSHOM.

Service Hydrographique et Océanographique de la Marine, 1968. Les courants de marée dans la Manche et sur les côtes françaises de l'Atlantique. S.H. 550, Imprimerie Nationale, Paris, 289 p.

Signell, R.P., Beardsley, R.C., Graber, H.C., Capotondi, A., 1990. Effect of wave-current interaction on wind-driven circulation in narrow, shallow embayments. Journal of Geophysical Research, 95, 9671-9678.

Smagorinsky, J., 1963. General circulation experiments with the primitive equations, i, the basic experiments. Monthly Weather Review 91, 99-164.

Soulsby, R.L., Hamm, L., Klopman, G., Myrhaug, D., Simons, R.R. et Thomas, G.P., 1993. Wave-current interaction within and outside the bottom boundary layer. Coastal Engineering, 21, 41-69.

Soulsby, R.L., 1983. The bottom boundary layer of shelf seas. In Physical Oceanography of Coastal and Shelf Seas. Ed. Johns, B., Elsevier, Amsterdam, 189-266.

Steinhorn, I., 1991. Salt flux and evaporation. Journal of Physical Oceanography. 21, 1681-1683.

SWAN team, 2009. SWAN Cycle III Version 40.72 AB - Scientific and Technical Documentation. Technical Report, Delft University of Technology, $107 \mathrm{pp}$

UNESCO, 1981. Tenth report of the joint panel on oceanographic tables and standards. UNESCO Technical Papers in Marine Science. number 36, UNESCO, Paris.

Zhang, H., Madsen, O.S., Sannasiraj, S.A. and Chan, E.S., 2004. Hydrodynamic model with wave-current interaction in coastal regions. Estuarine, coastal and shelf science, 61, 317-324. 